\title{
Study of Vitamin D Receptor Gene Polymorphisms in Egyptian Patients with Primary Osteoporosis
}

\author{
Rania R. Ahmed ${ }^{1}$, Ahmed O. Mostafa ${ }^{2}$, Eman M. Saleh ${ }^{2}$, Hala Nasr ${ }^{1}$ and Laila K. E. Effat ${ }^{1 *}$ \\ ${ }^{I}$ Deptartment of Medical Molecular Genetics, Human genetics and genome research Division, National Research \\ Center, Giza, Egypt, \\ ${ }^{2}$ Department of Biochemistry, Faculty of Science, Ain Shams University, 11566 Abbassia, Cairo, Egypt,
}

ARTICLE INFO

Article history:

Received 28 October 2015

Accepted 16 November 2015

Keywords:

Osteoporosis;

Polymorphism;

BMD;

VDR;

PCR-RFLP.

\begin{abstract}
A B S T R A C T
Osteoporosis is a common skeletal disease characterized by a generalized reduction in bone mineral density (BMD), architectural deterioration of bone tissue and increased risk of fracture. Primary osteoporosis is the most common type and is more frequent in postmenopausal women caused by severe decrease in serum estrogen levels after cessation of the ovarian function. A genetic contribution to the pathogenesis of osteoporosis has been recognized. One of the first genes to be studied for its association with osteoporosis is that for the Vitamin D receptor (VDR). To investigate the association of four polymorphisms (TaqI, ApaI, BsmI, FokI); characterized by the ability to distinguish between different polymorphisms by digestion with the restriction endonucleases; of VDR gene to BMD and to estimate the frequencies of those different polymorphic genotypes in a study population. In a pilot study, sixty five Egyptian women with primary osteoporosis were selected according to measurements of DEXA test. In addition, thirty women who did not suffer of any skeletal disorder were also included in the study as control subjects. Genomic DNA was extracted from peripheral blood leukocytes using the salting out procedure. Polymerase chain reaction -restriction fragment length polymorphism (PCR-RFLP) was performed to identify the VDR genotype of the four chosen polymorphic loci. We found a close association of specific genotypes of the four studied polymorphisms in the VDR gene with low BMD in Egyptian patients with primary osteoporosis. Based on the data obtained in this study as well as several other community-specific profiles, the four selected polymorphisms of the VDR gene were proved to be reliable, simple, cheap and non-invasive markers to detect susceptibility to osteoporosis, thus lead to better management of primary osteoporosis cases and reduce or delay the pathogenic consequences of the disease.
\end{abstract}

\section{Introduction}

Remodeling is a process that involves continuous removal of discrete packets of old bone from the skeleton (a sub process called bone resorption), replacement of these packets with newly synthesized proteinaceous matrix, and subsequent mineralization of the matrix to form new bone (a sub process called ossification or bone formation). Osteoporosis (OMIM: 166710) is a systemic skeletal disease in which bones become fragile and more likely to break ${ }^{[1]}$. It is a common disease that is characterized by low bone mass, disturbed microarchitecture and composition of bone tissue, and susceptibility to nontraumatic fracture ${ }^{[2,3]}$.

\footnotetext{
* Corresponding author.

E-mail address: lailaeffat@yahoo.com
}

Osteoporotic fracture, especially those of the hip and spine, is a serious manifestation of osteoporosis and could affect the quality of life of the sufferer ${ }^{[4]}$.

Primary osteoporosis is a disease of the elderly, particularly among older women, with most cases occurring in the sixth and later decades of life. It is estimated that osteoporosis can affect $30-50 \%$ of women and $15-30 \%$ of men ${ }^{[5]}$. Osteoporosis is a polygenic disorder, determined by the effects of several genes, each with relatively modest effects on bone mass and other determinants of fracture risk ${ }^{[5]}$.

In last years, candidate gene association studies (CGAS) have explored the association between osteoporosis and polymorphisms in candidate genes. Several genes have been characterized to be involved in bone mineral home 
ostasis, bone remodeling and bone matrix composition, e.g. vitamin $\mathrm{D}$ receptor (VDR) gene ${ }^{[6]}$, estrogen receptor ${ }^{[7-9]}$, collagen type $1 \mathrm{~A} 1$ (COL1A1) $^{[10]}$, and transforming growth factor B1(TGFB1) ${ }^{[11]}$.

The VDR gene is located on chromosome 12q13.11 and is made up of $5.6 \mathrm{~kb}$. In response to hormone binding (1, $\left.25(\mathrm{OH})_{2} \mathrm{D}_{3}\right)$, VDR regulates the transcriptional activity of vitamin D3-responsive genes by complexing with a vitamin-D response element located in the promoter region of target genes. Allelic variation in VDR causes significant alteration in the activity of the receptor and thus the subsequent downstream vitamin-D mediated effects such as calcium absorption, excretion and modulation of cellular proliferation and differentiation. In fact, VDR was the first candidate gene to be studied in relation to osteoporosis, and most attention has focused on polymorphisms situated near the 3'flank of VDR recognized by the restriction enzymes BsmI, ApaI, $\operatorname{TaqI}{ }^{[12]}$, and FokI in the translation initiation codon of exon $2^{[13]}$.

Allelic variants of the gene encoding VDR, recognized by ApaI (allele A/a), BsmI (allele B/b), FokI (allele F/f) and $\operatorname{Taq} \mathrm{I}$ (allele $\mathrm{T} / \mathrm{t}$ ) restriction endonucleases have been associated with Bone Mass Density (BMD) in many studies. These Allelic variants are used in defining the community specific haplotype of osteoporosis, which is a set of DNA variations, or polymorphisms, that tend to be inherited together ${ }^{[14]}$.

The FokI polymorphism is a T/C transition polymorphism (ATG to ACG) at the first of two potential translation initiation sites in exon 2 which is referred as a start codon polymorphism (SCP) has been detected by using the FokI restriction endonuclease. On the other hand, the three adjacent RFLPs for BsmI, ApaI and $T a q \mathrm{I}$, respectively, in intron 8/ exon 9 at the 3 'end of the Vitamin D receptor gene, have been most frequently studied. The TaqI polymorphism is a T/C nucleotide substitution (ATT to ATC) leading to a synonymous change at codon 352 (isoleucine) in exon 9. Bsm I (T/G) and $A p a \mathrm{I}(\mathrm{G} / \mathrm{A})$ restriction site polymorphisms occur in the intron separating exons 8 and $9{ }^{[15]}$. These polymorphisms can be distinguished by digestion with the respective restriction enzymes. The presence or absence of restriction site defines the specific allele.

The aim of this study was to investigate the association of four selected polymorphisms (FokI, TaqI, ApaI, BsmI) of VDR gene with BMD in a study of Egyptian osteoporotic women and to detect the incidence of any specific genotype with the development of osteoporosis.

\section{Subjects and Methods \\ Subjects}

This study included 65 of female Egyptian patients (3064 years) who were diagnosed with primary osteoporosis (cases with osteoporosis secondarily to other disorders such as endocrine, congenital, metabolic disorders or malignancies were excluded) with mean age of 51.9 \pm 6.31 and 30 healthy Egyptian women who were included as controls (33-60 years), with mean age of
46.6 \pm 7.4. Patients were chosen from National Research Center (NRC) clinical center. All subjects signed consent forms according to the guidelines of the ethical committee of the NRC prior to clinical evaluation.

\section{Methods}

\section{DEXA measurement}

All patients were subjected to bone mineral density (BMD) measurement using the Dual Energy X-ray Absorptiometry (DEXA, Hologic QDR 4,500 W) both at the lumbar spine (anterio-posterior projection of L1-L4) and the proximal femur (total score). In DEXA analysis, $\mathrm{BMD}$ data is expressed as $\mathrm{g} / \mathrm{cm}^{2}$ and SD scores compares individual BMD determinations to those of 35year old healthy individual ${ }^{[16]}$.

\section{Polymerase chain reaction}

Peripheral blood samples were collected for DNA extraction in EDTA-containing vacutainers. Genomic DNA was extracted using a standard salting out procedure as previously described by Miller et al. [17]. Genotyping of the four VDR polymorphisms was carried out by PCR amplification followed by RFLP analysis of the PCR products (PCR-RFLP). The VDR genotype of each subject was identified according to the digestion pattern and alleles according to the presence (f, t, b, and a) or the absence (F, T, B, and A) of the FokI, TaqI, BsmI and ApaI, restriction enzyme recognition sites, respectively .

VDR variants were amplified from each sample as follows: Four polymorphic sites in the VDR gene (Accession number: AY342401.1) were chosen to be amplified and subsequently analyzed with the restriction enzymes TaqI, FokI, BsmI and ApaI. The PCR reactions were set up in $25-\mu \mathrm{l}$ reaction volume containing $0.5 \mu \mathrm{g}$ genomic DNA, 10x PCR buffer, $0.25 \mathrm{mM}$ dNTPs, 2.5 pmol of each primer (MWG-Biotech, Germany) and 2 units of Taq polymerase. PCR was carried out on Perkin Elmer thermal cycler (Applied Biosystem 2720) using an initial denaturation step for $5 \mathrm{~min}$, followed by 35 cycles of denaturation at $94^{\circ} \mathrm{C}$ for $30 \mathrm{sec}$, annealing at the respective temperature (Table 1) for $30 \mathrm{sec}$, and extension at $72^{\circ} \mathrm{C}$ for 1 min followed by a final extension at $72^{\circ} \mathrm{C}$ for $7 \mathrm{~min}$.

\section{VDR genotyping}

PCR-amplified products were purified using PCR purification kit (Promega, USA), then $10 \mu$ l of purified PCR products were digested with $10 \mathrm{U}$ of the respective restriction enzyme (Fermentas, Germany). Enzyme reactions were incubated at $37^{\circ} \mathrm{C}$ (except for TaqI reactions, which were incubated at $65^{\circ} \mathrm{C}$ ), for 2 hours. Digestion products were then separated by electrophoresis onto $2 \%$ agarose gel and stained with ethidium bromide, where separation of uncut PCR product indicated the absence of the recognition sequence of the used restriction enzyme, while presence of the cut site resulted in separation of the restriction fragments specific for each enzyme (Table 2). In either case, presence or absence of the particular cut site, indicated presence of homozygote genotype, while in 
case of heterozygote genotype, both the uncut PCR product and the specific restriction fragments were present and separated on the gel.

\section{Statistical analysis}

Data was expressed descriptively as percentages for qualitative values and mean \pm standard deviation (SD) for quantitative parametric data. The complied data was computerized and analyzed by SPSS software package, version 16. The following tests of significance were used: analysis of variance (ANOVA) test between more than 2 means, $t$-test between means was used to analyze mean difference. Comparison of qualitative data was done using chi square test and cross tabs. A level of significance with $\mathrm{p} \leq 0.05$ was considered significant, $\mathrm{p}$ $\leq 0.01$ was considered of high significance and $\mathrm{p}>0.05$ insignificant.

Table 1: The primers used in the PCR amplification of the four different VDR polymorphic loci.

\begin{tabular}{|c|c|c|c|}
\hline Polymorphism & Primer sequence & $\begin{array}{c}\text { Annealing } \\
\text { temperature }\end{array}$ & References \\
\hline FokI & $\begin{array}{l}\text { F; 5'-AGCTGGCCCTGGCACTGACTCTG-3' (23) } \\
\text { Location: } 10416238-10416260 \\
\text { R; 5'-ATGGAAACACCTTGCTTCTTCTCCCTC-3' (27) } \\
\text { Location: } 10415994-10416020\end{array}$ & $7^{\circ} \mathrm{C}^{*}$ & {$[18]$} \\
\hline $\operatorname{Taq} \mathbf{I}$ & $\begin{array}{l}\text { F; 5'-CAGAGCATGGACAGGGAGCAA-3' (21) } \\
\text { Location: } 10382336-10382356 \\
\text { R; 5'-CACTTCGAGCACAAGGGGCGTTAGC-3' (25) } \\
\text { Location: } 10381856-10381880\end{array}$ & $61^{\circ} \mathrm{C}$ & [19] \\
\hline ApaI & $\begin{array}{l}\text { F; 5'-CAGAGCATGGACAGGGAGCAAG-3' (22) } \\
\text { Location: } 10382335-10382356 \\
\text { R; 5'-GCAACTCCTCATGGCTGAGGTCTCA-3' (25) } \\
\text { Location: } 10381612-10381636\end{array}$ & $65^{\circ} \mathrm{C}$ & [20] \\
\hline BsmI & $\begin{array}{l}\text { F; 5'-CAACCAAGACTCAAGTACCGCGTCAGTGA-3' (29) } \\
\text { Location: } 10383757-10383786 \\
\text { R; 5'-AACCAGCGGAAGAGGTCAAGGG-3' (22) } \\
\text { Location: } 10382965-10382986\end{array}$ & $7^{\circ} C^{*}$ & [21] \\
\hline
\end{tabular}

*In these reactions, the annealing step was omitted and the extension step was carried out at $70^{\circ} \mathrm{C}$ instead of $72^{\circ} \mathrm{C}$.

Table 2: Restriction fragment patterns resulted from digestion with the used restriction endonucleases.

\begin{tabular}{|c|c|c|c|}
\hline \hline Polymorphism & Location & $\begin{array}{c}\text { Size of undigested PCR } \\
\text { products (bp) }\end{array}$ & $\begin{array}{c}\text { Length of restriction } \\
\text { fragments produced (bp) }\end{array}$ \\
\hline \hline Fok I & Exon 2 & 267 & 196,71 \\
\hline TaqI & Intron 8/Exon 9 & 501 & 296,205 \\
\hline ApaI & Intron 8/Exon 9 & 745 & 525,220 \\
\hline Bsm I & Exon 7/Intron 8 & 822 & 650,172 \\
\hline \hline
\end{tabular}

\section{Results}

\section{DEXA results}

BMD was measured in all patients and controls by DEXA scan in both the lumbar spine and the proximal femur (Table 3). DEXA results showed that 33 females had osteoporosis while 32 females had osteopenia. On the other hand, no osteoporosis was found in the 30 control females established by their DEXA examination.

\section{Molecular studies}

The distributions of TaqI, FokI, BsmI and ApaI polymorphisms in osteoporotic women and controls are shown in Figures (1-4) and Table (4).

From these results, the most significant VDR variants among patients were $\mathrm{Ff}(\mathrm{p}=0.007)$, tt $(\mathrm{p}=0.002)$, Aa $(\mathrm{p}=0.002)$ and BB $(\mathrm{p}=0.002)$ in FokI, TaqI, ApaI and BsmI loci, respectively. 
Table 3: Demographic data of BMD and DEXA analysis.

\begin{tabular}{|c|c|c|c|c|c|c|c|c|}
\hline \multicolumn{2}{|c|}{ Groups } & Age & Weight & Height & $\begin{array}{l}\text { Mean of } \\
\text { BMD of } \\
\text { Femur }\end{array}$ & $\begin{array}{c}\text { Mean of } \\
\text { BMD of } \\
\text { Spine }\end{array}$ & $\begin{array}{c}\text { T-Score of } \\
\text { Femur }\end{array}$ & $\begin{array}{l}\text { T-Score of } \\
\text { Spine }\end{array}$ \\
\hline \multirow{2}{*}{$\begin{array}{l}\text { Patients } \\
\mathrm{N}=(65)\end{array}$} & Mean & 51.87 & 75.02 & 157.64 & 0.64 & 0.91 & -2.20 & -1.26 \\
\hline & SD & 6.32 & 11.19 & 5.67 & 0.07 & 0.12 & 0.65 & 0.78 \\
\hline \multirow{2}{*}{$\begin{array}{l}\text { Controls } \\
\mathrm{N}=(\mathbf{3 0})\end{array}$} & Mean & 46.60 & 79.42 & 160.87 & 0.84 & 1.14 & -0.32 & 0.18 \\
\hline & SD & 7.37 & 9.20 & 5.76 & 0.09 & 0.13 & 0.87 & 0.70 \\
\hline
\end{tabular}

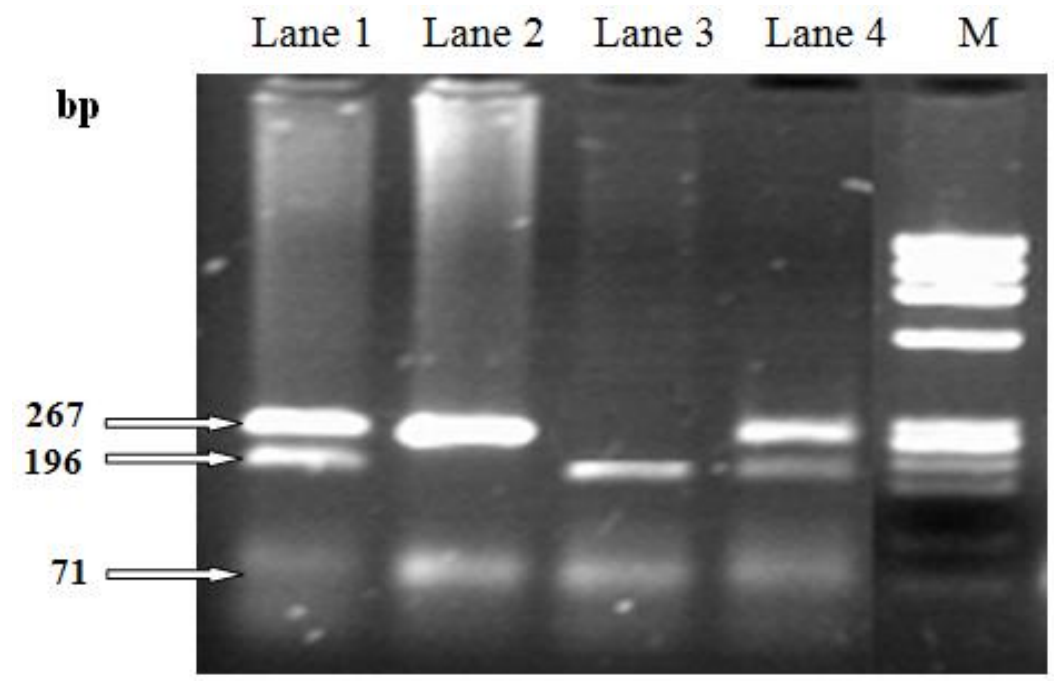

Fig. 1: A $2 \%$ agarose gel stained with ethidium bromide illustrating the digestion of PCR products of FokI locus of the VDR gene with FokI enzyme. Lanes 1and 4, two patients with Ff genotype (267 bp, 196 bp and 71 bp); Lane 2, one patient with FF genotype (267 bp); Lane 3, one patient with ff genotype (196 bp and 71 bp); M, Molecular size marker (PhiX174 DNA/HaeIII; 1353, 1078, 872, 603, 310, 281, 271, 234, 194, 118 and 72 bps).

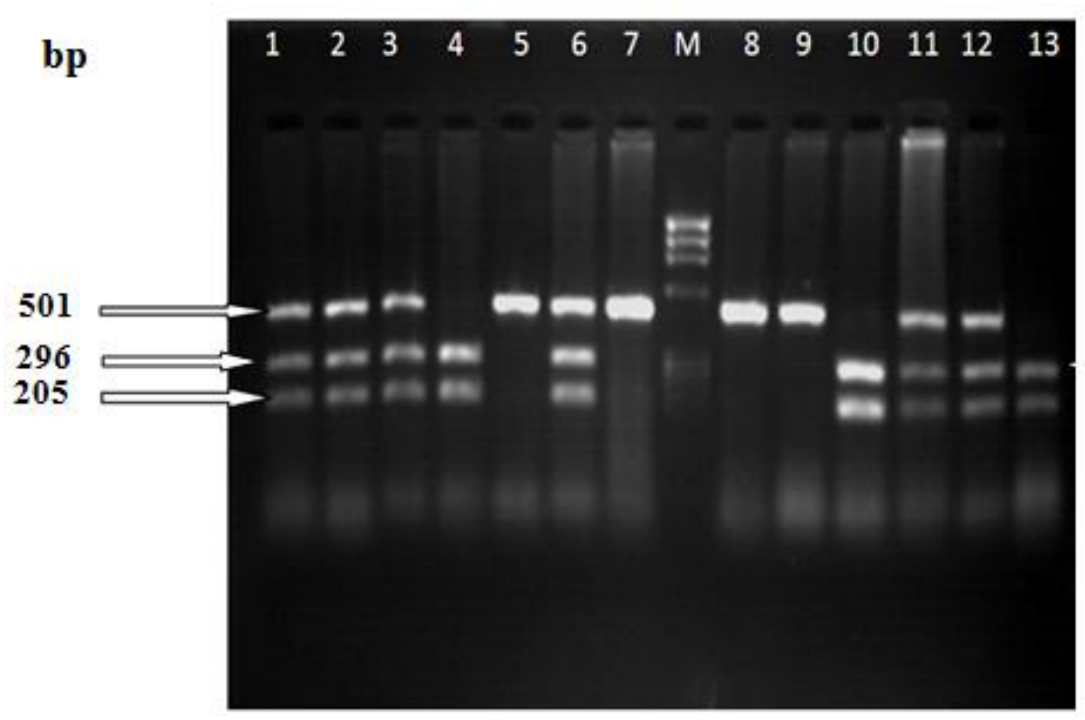

Fig. 2: A $2 \%$ agarose gel stained with ethidium bromide illustrating the digestion of PCR products of TaqI locus of the VDR gene with TaqI enzyme. Lanes 1, 2, 3, 6, 11 and 12, six patients with Tt genotype (501, 296, 205 bp); Lanes 4, 10 and 13, three patients with tt genotype (205, $296 \mathrm{bp})$; Lanes 5, 7, 8 and 9, four patients with TT genotype (501bp); M, Molecular size marker (PhiX174 DNA/HaeIII; 1353, 1078, 872, 603, 310, 281, 271, 234, 194, 118 and $72 \mathrm{bps}$ ). 


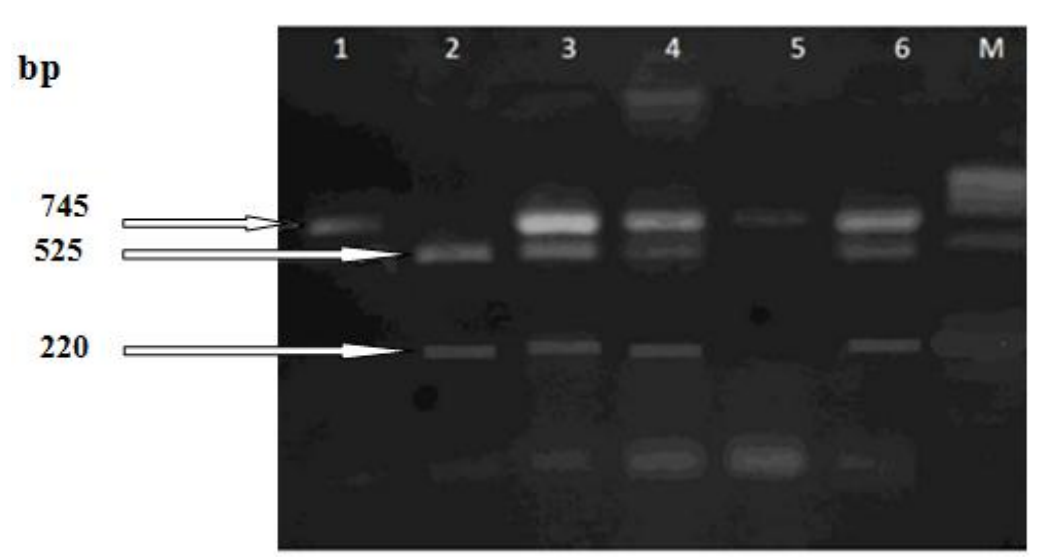

Fig. 3: A 2\% agarose gel stained with ethidium bromide illustrating the digestion of PCR products of ApaI locus of the VDR gene with ApaI enzyme. Lanes 1, 3, 4 and 6, four patients with Aa genotype (745, 525, 220 bp); Lane 2, one patient with aa genotype $(525,220 \mathrm{bp})$; Lane 5, one patient with AA genotype (745 bp); M, Molecular size marker (PhiX174 DNA/HaeIII; 1353, 1078, 872, 603, 310, 281, 271, 234, 194, 118 and 72 bps).

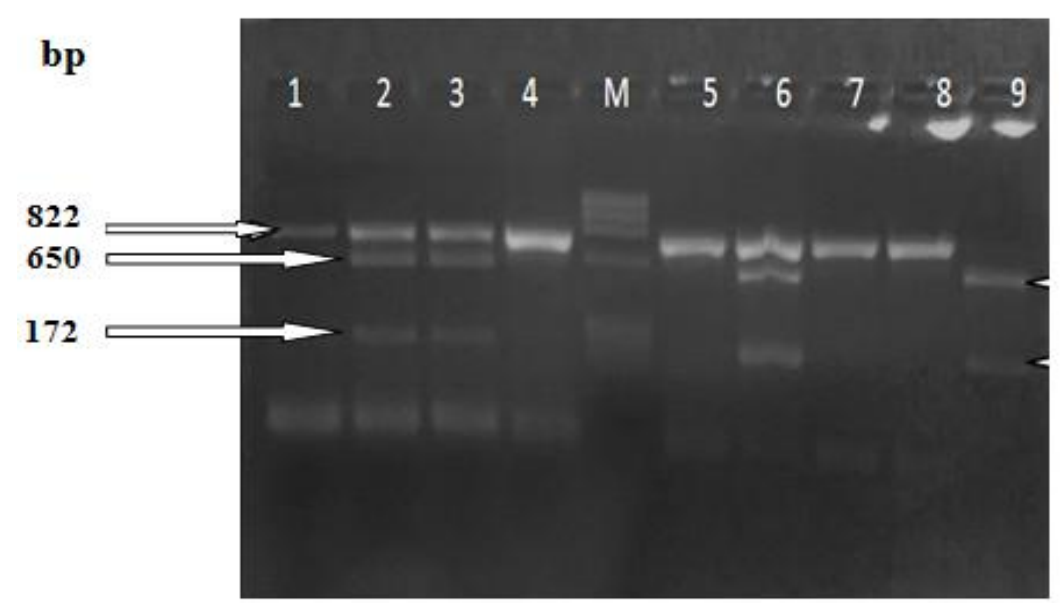

Fig. 4: A 2\% agarose gel stained with ethidium bromide illustrating the digestion of PCR products of BsmI locus of the VDR gene with BsmI enzyme. Lanes 1, 2, 3 and 6, four patients with Bb genotype (822, 650, 172 bp); Lane 9, one patient with bb genotype (650, 172 bp); Lanes 4, 5, 7 and 8, four patients with BB genotype (822bp); M, Molecular size marker (PhiX174 DNA/HaeIII; 1353, 1078, 872, 603, 310, 281, 271, 234, 194, 118 and 72 bps).

\section{Correlation of the VDR gene polymorphism and BMD}

The statistical correlation tests between the FokI, BsmI, ApaI and TaqI VDR gene polymorphisms and BMD of patients and control groups revealed a significant relationship between specific genotypes of VDR polymorphisms and BMD at the measured skeletal sites (both the lumbar spine and the proximal femur) (Table 5).

As for the correlation between VDR FokI genotypes and mean of BMD of patient and control groups, individuals with heterozygous wild genotype Ff showed a highly significant difference association with femoral hip BMD relative to control where it had the lowest hip BMD. On the contrary, individuals with homozygous wild FF genotype showed a highly significant association with lumbar spine BMD where it had the lowest spine BMD. Meanwhile, carriers of the FF and Ff genotypes had the highest hip and spine BMD, respectively.
In case of VDR TaqI genotype, individuals with the TT genotype had the lowest hip BMD relative to control while individuals with the homogeneous mutant tt genotype had the highest hip BMD. Conversely, in case of lumbar spine, individuals with the $\mathbf{t t}$ genotype had the lowest spine BMD while the Tt genotype had the highest spine BMD.

With respect to the ApaI genotype, individuals with the heterogeneous wild Aa genotype had the lowest mean of hip and spine BMD; furthermore, individuals with the aa genotype had both the highest hip and spine BMD values.

Regarding the $B s m \mathrm{I}$ polymorphism and its correlation to femoral hip BMD, the bb genotype was associated with lowest hip BMD while individuals with the BB genotype had the highest hip BMD. On the other hand, the BB genotype was associated with the lowest lumbar spine BMD while individuals with the $\mathbf{B b}$ genotype had the highest spine BMD. 
Table 4: Distribution of different genotypes of the four polymorphisms and alleles frequency in all groups.

\begin{tabular}{|c|c|c|c|c|}
\hline \multicolumn{2}{|c|}{ Polymorphism } & $\begin{array}{c}\text { Controls } \\
(\mathbf{n}=30)\end{array}$ & $\begin{array}{c}\text { Patients } \\
(n=65)\end{array}$ & $p$ value \\
\hline \multirow{5}{*}{ FokI } & FF genotype & $20(66.7 \%)$ & $441(63.1 \%)$ & $0.317(\mathrm{NS})$ \\
\hline & Ff genotype & $9(30 \%)$ & $18(27.7 \%)$ & $0.007 * *$ \\
\hline & ff genotype & $1(3.3 \%)$ & $6(9.2 \%)$ & $0.059(\mathrm{NS})$ \\
\hline & F allele $(\%)$ & $49(81.7 \%)$ & $100(76.9 \%)$ & - \\
\hline & f allele $(\%)$ & $11(18.3 \%)$ & $30(23.1 \%)$ & - \\
\hline \multirow{5}{*}{ TaqI } & TT genotype & $10(33.3 \%)$ & $15(23.1 \%)$ & $0.317(\mathrm{NS})$ \\
\hline & Tt genotype & $18(60 \%)$ & $35(53.8 \%)$ & $0.020^{*}$ \\
\hline & tt genotype & $2(6.7 \%)$ & $15(23.1 \%)$ & $0.002^{* *}$ \\
\hline & T allele (\%) & $38(63.3 \%)$ & $65(50 \%)$ & - \\
\hline & $\mathrm{t}$ allele $(\%)$ & $22(36.7 \%)$ & $65(50 \%)$ & - \\
\hline \multirow{5}{*}{ Apa I } & AA genotype & $10(33.3 \%)$ & $21(32.3 \%)$ & $0.048^{*}$ \\
\hline & Aa genotype & $16(53.3 \%)$ & $39(60.0 \%)$ & $0.002 * *$ \\
\hline & aa genotype & $4(13.3 \%)$ & $5(7.7 \%)$ & $0.739(\mathrm{NS})$ \\
\hline & A allele $(\%)$ & $36(60.0 \%)$ & $81(62.3 \%)$ & - \\
\hline & a allele $(\%)$ & $24(40 \%)$ & $49(37.7 \%)$ & - \\
\hline \multirow{5}{*}{ BsmI } & BB genotype & $7(23.3 \%)$ & $24(36.9 \%)$ & $0.002 * *$ \\
\hline & Bb genotype & $16(53.3 \%)$ & $25(38.5 \%)$ & $0.160(\mathrm{NS})$ \\
\hline & bb genotype & $7(23.3 \%)$ & $16(24.6 \%)$ & $0.061(\mathrm{NS})$ \\
\hline & B allele $(\%)$ & $30(50 \%)$ & $73(56.2 \%)$ & - \\
\hline & $\mathrm{b}$ allele $(\%)$ & $30(50 \%)$ & $57(43.8 \%)$ & - \\
\hline
\end{tabular}

Where: NS indicates non significant, $(*)$ indicates significant, and ** indicates highly significant.

Table 5: Correlation between the different VDR genotypes with BMD.

\begin{tabular}{|c|c|c|c|c|c|c|c|}
\hline \multirow{2}{*}{ Polymorphism } & \multirow{2}{*}{ Genotype } & \multicolumn{3}{|c|}{ Femoral hip } & \multicolumn{3}{c|}{ Lumbar spine } \\
\cline { 3 - 8 } & & Patient & Control & $\boldsymbol{p}$ value & Patient & Control & $\boldsymbol{p}$ value \\
\hline \hline \multirow{3}{*}{ FokI } & $\mathbf{f f}$ & 0.6358 & 0.7370 & $0.149(\mathrm{NS})$ & 0.9140 & 1.0360 & $0.439(\mathrm{NS})$ \\
\cline { 2 - 8 } & $\mathbf{F f}$ & 0.6246 & 0.8596 & $0.000^{* *}$ & 0.9286 & 1.1879 & $0.000^{* *}$ \\
\cline { 2 - 8 } & $\mathbf{F F}$ & 0.6435 & 0.8296 & $0.000^{* *}$ & 0.9035 & 1.1292 & $0.000^{* *}$ \\
\hline \multirow{3}{*}{ TaqI } & $\mathbf{t t}$ & 0.6474 & 0.7690 & $0.082(\mathrm{NS})$ & 0.8841 & 1.1325 & $0.004^{* *}$ \\
\cline { 2 - 8 } & $\mathbf{T t}$ & 0.6406 & 0.8459 & $0.000^{* *}$ & 0.9295 & 1.1476 & $0.000^{* *}$ \\
\cline { 2 - 8 } & $\mathbf{T T}$ & 0.6205 & 0.8301 & $0.000^{* *}$ & 0.8967 & 1.1400 & $0.000^{* *}$ \\
\hline \multirow{3}{*}{ ApaI } & $\mathbf{a a}$ & 0.6540 & 0.8618 & $0.016^{*}$ & 0.9466 & 1.1832 & $0.007^{* *}$ \\
\cline { 2 - 8 } & $\mathbf{A a}$ & 0.6293 & 0.8271 & $0.000^{* *}$ & 0.9021 & 1.1113 & $0.000^{* *}$ \\
\cline { 2 - 8 } & $\mathbf{A A}$ & 0.6489 & 0.8382 & $0.000^{* *}$ & 0.9203 & 1.1779 & $0.000^{* *}$ \\
\hline \multirow{3}{*}{ BsmI } & $\mathbf{b b}$ & 0.6226 & 0.8410 & $0.000^{* *}$ & 0.9094 & 1.2061 & $0.000^{* *}$ \\
\cline { 2 - 8 } & $\mathbf{B b}$ & 0.6358 & 0.8449 & $0.000^{* *}$ & 0.9255 & 1.1278 & $0.000^{* *}$ \\
\cline { 2 - 8 } & $\mathbf{B B}$ & 0.6493 & 0.8107 & $0.000^{* *}$ & 0.8981 & 1.1174 & $0.000^{* *}$ \\
\hline \hline
\end{tabular}

Where: NS indicates non significant, $(*)$ indicates significant, and ** indicates highly significant.

Table 6: The most specific haplotypes associated with osteoporosis.

\begin{tabular}{|c|c|c|}
\hline \hline Genotype & Haplotype & $\boldsymbol{p}$ value \\
\hline \hline TtFFAa & TFA & 0.05 \\
\hline $\mathrm{ttFFAA}$ & $\mathrm{tFA}$ & 0.02 \\
\hline $\mathrm{ttAABB}$ & $\mathrm{tAB}$ & 0.008 \\
\hline $\mathrm{ttFFBB}$ & $\mathrm{tFB}$ & 0.007 \\
\hline FFAabb & $\mathrm{FAb}$ & 0.02 \\
\hline $\mathrm{ttFFAABB}$ & $\mathrm{tFAB}$ & 0.02 \\
\hline \hline
\end{tabular}




\section{Haplotypes of VDR gene polymorphism related to osteoporosis}

Combining the different genotypes showed that the combination TtFFAa, ttFFAA, ttAABB, ttFFBB, FFAabb and ttFFAABB were the most specific haplotypes which considered as risk factors to the susceptibility to osteoporosis (Table 6).

\section{Discussion}

The VDR gene is the first gene studied in relation to osteoporosis. It is known to regulate the transcription of target genes (e.g., calcium-binding protein and osteocalcin) that are crucial for calcium absorption and bone formation. The mechanism by which the VDR gene affects BMD remains unknown. In addition, polymorphisms in the VDR gene and other genes and pathways, such as the estrogen signaling pathway, transforming growth factor-beta superfamily, and the activating receptor of the nuclear factor $\kappa \mathrm{B}$ (RANK) signaling pathway, can affect $\mathrm{BMD}$ and regulate the effect of the VDR gene polymorphisms on BMD ${ }^{[22]}$.

Genetic association studies in osteoporosis found associations between the VDR polymorphisms and osteoporosis. Gong et al. ${ }^{[23]}$ concluded that BMD is associated with VDR genotype, especially in females before the menopause. Similarly, our study found such an association of single alleles of the VDR to osteoporosis and revealed that the single alleles $\mathrm{F}$ (76.9\%), t (50\%), A (62.3\%), and B (56.2\%) of FokI, TaqI, ApaI, and BsmI polymorphic loci, respectively, were overrepresented in patients compared to controls. On the other hand, a Dutch study on elderly women and men by Uitterlinden $\boldsymbol{e t}$ al. ${ }^{[24]}$ showed no effect of single polymorphism on BMD, but a small effect was detected employing haplotype pattern of the VDR gene. Such conflicting findings, which are not exclusive for the field of genetic association analysis of osteoporosis, could be due to the fact that the 3'Bsm-Apa-Taq polymorphic loci are non functional themselves, as the BsmI and ApaI RFLPs are located in intron 8 and are not affecting any splicing site and/or transcription factor binding site, and the TaqI RFLP is a "synonymous" polymorphism meaning that it is present in the coding sequence (i.e., exon 9) but it is not changing the amino acid sequence of the encoded protein ${ }^{[25]}$.

In fact, the alleles of the VDR gene are hypothesized to function differently and contribute to the physiologically diverse levels of osteocalcin (the most abundant noncollagenous bone protein) because the expression of osteocalcin is induced by calcitriol through VDR ${ }^{[26]}$. BsmI polymorphism in intron 8 of the VDR gene could be correlated to serum osteocalcin concentration, and was subsequently found to be associated with differences in BMD in a twin study in postmenopausal women ${ }^{[27]}$. Allelic variants of the gene encoding VDR, recognized by FokI (allele F/f), TaqI (allele T/t), ApaI (allele $\mathrm{A} / \mathrm{a}$ ), and $B s m \mathrm{I}$ (allele $\mathrm{B} / \mathrm{b}$ ) restriction endonucleases, have been associated with Bone Mass Density (BMD) in many studies, as well as with bone loss in elderly subjects and gain after 1,25-dihydroxy
Vitamin $\mathrm{D}_{3}$ treatment. These allelic variants are used in defining the community specific haplotype of osteoporosis $^{[14]}$.

Additionally, these polymorphisms have also been associated with bone remodeling process [25]. In agreement with our results, Moran et al. ${ }^{[22]}$ found that women with the BB genotype have reduced lumbar bone mass compared to those with the bb genotype. Women with the BB genotype experienced accelerated bone remodeling with increased bone resorption, higher observed degradation of collagen type I, and increased calcitriol and phosphate values. These observed phenomena produce long-term mineral loss from the skeleton and low BMD. The initial studies by Morrison et al. [26-28] suggested that the "B" allele of the BsmI RFLP-site is the risk allele associated with low BMD, other studies either could confirm this ${ }^{[29]}$, did not find any effect ${ }^{[30]}$, or reported the opposite ${ }^{(31)}$.

In the present study, our data showed the different frequencies of each genotype of the four polymorphisms of the VDR gene among the patient and control groups. Statistical analysis comparing the BMD to each genotype identified the degree of association of each polymorphism with osteoporosis. Also analysis of the different combination of genotypes with BMD revealed specific haplotypes which could be highly significant to identify disease susceptibility.

The analysis of the FokI polymorphism of the VDR gene showed that FF genotype was found to be the most prevalent genotype in patients and control groups, and was associated with low lumbar spine BMD values, a finding that was in concordance with a study by Kurt et al. ${ }^{[3]}$, who found that FF genotype was associated with low femoral neck and total hip BMD values. In the meantime, the Ff genotype was found to be associated with low femoral neck BMD values and was significantly prevalent in osteoporotic patients as compared to control group. On the contrary, Zajíčková et al. ${ }^{[32]}$ and Uitterlinden et al. ${ }^{[33]}$ found FF genotype was associated with higher BMD at femoral neck. Also, in Mexican-American postmenopausal women, the ff subjects were related with decreased BMD at the lumbar spine and increased rate of bone loss at the hip ${ }^{[22,34-36]}$. Both lumbar and femoral BMD were observed to be highest in "FF"' homozygous by Vidal et al. ${ }^{[37]}$ in postmenopausal Maltase women. On the other hand, MacDonald et al. ${ }^{[38]}$ and Langdahl et al. ${ }^{[39]}$ could not find any relation between BMD values and VDR FokI genotypes.

According to our study, the TaqI polymorphism of the VDR gene revealed that $\mathbf{T t}$ genotype was significantly higher than TT and tt in both patient and control group. On the other hand, the TT and tt genotypes were found to be correlated with the lowest mean of BMD in the hip and the lumbar spine, respectively. Similarly, the average BMD of the subjects with $\mathbf{T T}$ and $\mathbf{T t}$ genotypes was found to be significantly higher at the spine and hip than those with tt genotypes in postmenopausal Indian women ${ }^{[34]}$. Also, Morita et al. ${ }^{[40]}$ approved the bone 
loss at the lumbar spine in the premenopausal women from Japan with tt genotype which was significantly greater than that of subjects with Tt or TT. Douroudis et al. ${ }^{[41]}$ reported similar results which showed that TT genotype had a high risk for osteoporosis in postmenopausal women of Hellenic origin. In contrast with Langdahl et al. ${ }^{[39]}$ study, the BMD of the individuals with TT genotype was higher than $\mathbf{T t}$ and $\mathbf{t t}$ genotypes. Also, Duman et al. ${ }^{[42]}$ found that the osteoporotic group with the TT genotype had significantly higher femoral neck BMD values in respect to the $\mathbf{t t}$ genotype in Turkish postmenopausal women.

For the ApaI polymorphism of the VDR gene, results approved that Aa genotype was found to be associated with low BMD values in both lumbar spine and femoral neck. It was also found to be high significantly associated to osteoporotic patients when compared to control. Similarly, Mitra et al. ${ }^{[34]}$ showed that the subjects with Aa genotype had significantly lesser BMD than those with genotype aa. In disagreement with our study, Li et al. ${ }^{[3]}$ showed that the mean BMD at the femoral neck was significantly higher in the subjects with Aa genotype than those with aa genotype. Similarly, Dundar et al. ${ }^{[2]}$ found postmenopausal women with aa genotype, who had significantly lower BMD values at lumbar spines compared to persons with AA genotype, they also reported that ApaI genotype was not associated with BMD at proximal femur.

Regarding the fourth polymorphism studied, the BsmI, the obtained results showed that there was no significant difference within the patient group genotypes. The comparison of patients to controls revealed that BB genotype was found to be highly significantly associated to osteoporotic patients. The bb genotype was found to be correlated with the lowest mean of BMD in the hip while BB genotype was correlated with the lumbar spine. Results of Ivanova $\boldsymbol{e t}$ al. ${ }^{[44]}$ were in agreement with our results documenting that BB genotype was found to be more common in cases with low BMD and/or osteoporosis and inversely, bb genotype was less common in the Bulgarian population. Similar findings were observed in another study which reported that the BB genotype was associated with a more than twofold increased risk of hip fracture compared with the bb genotype ${ }^{[45]}$. Their findings were also consistent with the results obtained by Garnero et al. ${ }^{[46]}$. Jia et al. ${ }^{[47]}$ reported that the bb genotype was a protective factor in East Asians where they found that the bb genotype was associated with a significantly decreased risk of osteoporosis in overall comparisons. Subgroup analyses showed that the bb genotype had a decreased risk of developing osteoporosis in postmenopausal women in Africans rather than in Asians and Caucasians. These findings suggest that VDR BsmI polymorphism may be involved in the pathogenesis of osteoporosis.

Some investigations have found no relation between
VDR gene polymorphisms and BMD in different populations ${ }^{[48,49]}$. These controversies between different studies could be attributed to numerous reasons such as the environmental influence on bone mass ${ }^{[50]}$. However, different genotypes may also have diverse effects on different parts of the skeleton. This might explain why several studies did not find an association between VDR polymorphisms and BMD [51]. Other reasons for such inconsistencies between these studies can be attributed to various factors such as the sample size, study design, age, ethnic ancestry, and lifestyle factors (physical activity, obesity, calcium intake), all of which could affect gene regulation in different genotypes and subjects and result in BMD loss or gain ${ }^{[52]}$.

Regarding the relationship between the calcium homeostasis and VDR gene expression, Stathopoulou et al. ${ }^{[53]}$ revealed the increased risk of osteoporosis by $118 \%$ and $132 \%$ in presence of the $\mathbf{B}$ and $\mathbf{t}$ alleles, respectively, within the low calcium intake $(<680 \mathrm{mg} / \mathrm{d})$. On the other hand, Gennari et al. ${ }^{[54]}$ observed that the intestinal calcium absorption in postmenopausal Italian women was significantly lower in BB and $\mathbf{t t}$ genotypes than in bb and TT genotypes, respectively. Also, Zambrano-Morales et al. ${ }^{[55]}$ found that BBAAtt genotype was a risk factor for osteoporosis while BbaaTT was a protection factor in postmenopausal Spanish women. On the other hand, Li et al. ${ }^{[43]}$ showed that $B s m \mathrm{I}$ and $A p a \mathrm{I}$ polymorphisms are weakly associated with BMD at some skeletal sites in the Chinese postmenopausal women, with heterozygous subjects had a higher BMD. Zhang et al. ${ }^{[56]}$ found that cross genotyping of ApaI and BsmI or TaqI polymorphisms was not associated with BMD in postmenopausal women. In conclusion, this study proved that the four polymorphisms chosen were associated with osteoporosis and several community-specific profiles were found that may be used as indicators for susceptibility of osteoporosis. Also, subjects with the specific haplotype ttFFAABB are more susceptible to osteoporosis and should be advised to start early with preventive measures (supplementation of calcium and vitamin D, exposure to sun and weight bearing exercise) in order to minimize the risk of becoming osteoporotic.

\section{References}

1) Graat-Verboom, L., Wouters, E. F. M., Smeenk, F. W. J. M., van den Borne, B. E. E. M., Lunde, R. and Spruit, M. A. (2009). Current status of research on osteoporosis in COPD: a systematic review. Eur. Respir. J., 34:209-218.

2) Dundar, U., Solak, M., Kavuncu, V., Ozdemir, M., Cakir, T., Yildiz, H. and Evcik, D. (2011). Evidence of association of Vitamin D receptor ApaI gene polymorphism with bone mineral density in postmenopausal women with osteoporosis. Clin. Rheumatol., 28:1187-1191.

3) Kurt, O., Yilmaz-Aydogan, H., Uyar, M., Isbir, T., Seyhan, M. F. and Can, A. (2012). Evaluation of 
ERa and VDR gene polymorphisms in relation to bone mineral density in Turkish postmenopausal women. Mol. Biol. Rep., 39:6723-6730.

4) Liu, J. L., Zhang, S. Q. and Zeng, H. M. (2013). ApaI, BsmI, FokI and TaqI polymorphisms in the vitamin $\mathrm{D}$ receptor (VDR) gene and the risk of psoriasis: a meta-analysis. J. Eur. Acad. Dermatol. Venereol., 27(6):739-46.

5) The National Osteoporosis Foundation (NOF) (2008). Clinician's guide to prevention and treatment of osteoporosis. Washington, DC: National Osteoporosis Foundation.

6) Fang, Y., van Meurs, J. B., d'Alesio, A., Jhamai, M., Zhao, H., Rivadeneira, F., Hofman, A., van Leeuwen, J. P. T., Jehan, F., Pols, H. A. P. and Uitterlinden, A. G. (2005). Promoter and 3'untranslated-region haplotypes in the vitamin $\mathrm{D}$ receptor gene predispose to osteoporotic fracture: the Rotterdam study. Am. J. Hum. Genet., 77:807823.

7) Ioannidis, J. P., Ralston, S. H., Bennett, S. T., Brandi, M. L., Grinberg, D., Karassa, F. B., Langdahl, B., van Meurs, J. B., Mosekilde, L. and Scollen, S. (2004). Differential genetic effects of ESR1 gene polymorphisms on osteoporosis outcomes. JAMA; 292:2105-2114.

8) Ioannidis, J. P., Stavrou, I., Trikalinos, T. A., Zois, C., Brandi, M. L., Gennari, L., Albagha, O., Ralston, S. H. and Tsatsoulis, A. (2002). Association of polymorphisms of the estrogen receptor alpha gene with bone mineral density and fracture risk in women: a meta-analysis. J. Bone Miner. Res., 17:2048-2060.

9) Gennari, L., Merlotti, D., De Paola, V., Calabro, A., Becherini, L. and Martini, G. (2005). Estrogen receptor gene polymorphisms and the genetics of osteoporosis: a Huge review. Am. J. Epidemiol., 161:307-320.

10) Mann, V. and Ralston, S. H. (2003). Meta-analysis of COL1A1 Sp1 polymorphism in relation to bone mineral density and osteoporotic fracture. Bone; 32:711-717.

11) Yamada, Y. (2001). Association of polymorphisms of the transforming growth factor-beta1 gene with genetic susceptibility to osteoporosis. Pharmacogenetics, 11:765-771.

12) Ferrari, S. (2008). Human genetics of osteoporosis. Best Pract. Res. Clin. Endocrinol. Metab., 22:723735.

13) Ralston, S. H. and de Crombrugghe, B. (2006). Genetic regulation of bone mass and susceptibility to osteoporosis. Genes \& Development, 20:24922506.

14) Genetics

Home

Reference:

(www.ghr.nlm.nih.gov).

15) Bhanushali, A. A., Lajpal, N., Kulkarni, S. S., Chavan, S. S., Bagadi, S. S. and Das, B. R. (2009). Frequency of FokI and TaqI polymorphism of vitamin D receptor gene in Indian population and its association with 25-hydroxyvitamin D levels. Indian Journal of Human Genetics, 15:108-113.

16) Kanis, J. A., Melton, L. J., Christiansen, C., Johnston, C. C. and Khaltaev, N. (1994). The diagnosis of osteoporosis. J. Bone Miner. Res., 9:1137-1141.

17) Miller, S. A., Dykews, D. and Polesky, H. F. (1988). A simple salting out procedure for extracting DNA from human nucleated cells. Nucleic Acids Res., 16:1215-1225.

18) Harris, S. S., Eccleshall, T. R., Gross, C., DawsonHughes, B. and Feldman, D. (1997). The vitamin D receptor start codon polymorphism (FokI) and bone mineral density in premenopausal American Black and White women. J Bone Miner. Res., 12:10431048.

19) Riggs, B. L., Nguyen, T. V., Melton, L. J., Morrison, N. A., O'Fallon, W. M., Kelly, P. J., Egan, K. S., Sambrook, P. N., Muhs, J. M. and Eisman, J. A. (1995). The contribution of vitamin D receptor gene alleles to the determination of bone mineral density in normal and osteoporotic women. J. Bone Miner. Res., 10:991-996.

20) Kung, A. W. C., Yeung, S. S. C. and LAU, K. S. (1998). Vitamin D receptor gene polymorphisms and peak bone mass in southern Chinese women. Bone, 22:389-393.

21) Bid, H. K., Mishra, D. K. and Mittal, R. D. (2005). Vitamin-D Receptor (VDR) Gene (Fok-I, Taq-I \& Apa-I) Polymorphisms in Healthy Individuals from North Indian Population. Asian Pacific J. Cancer Prev.; 6:147-152.

22) Moran, J. M., Rodriguez-Velasco, F. J., RonceroMartin, R., Rey-Sanchez, P., Martinez, M. and Pedrera-Zamorano, J. D. (2014). The Relationship between Polymorphisms in the Vitamin D Receptor Gene and Bone Mineral Density in Postmenopausal Women. ISRN Genetics, 2014:1-7.

23) Gong, G., Stern, H. S., Cheng, S. C., Fong, N., Mordeson, J., Deng, H. W. and Recker, R. R. (1999). The association of bone mineral density with Vitamin D receptor gene polymorphisms. Osteop. Int., 9:55-64.

24) Uitterlinden, A. G., Pols, H. A. P., Burger, H., Huang, Q., van Daele, P. L. A., van Duijn, C. M., Hofman, A., Birkenhäger, J. C. and van Leeuwen, J. P. T. M. (1996). A large scale population based study of the association of Vitamin D receptor gene polymorphisms with bone mineral density. J. Bone Miner. Res., 11: 1242-1248.

25) Uitterlinden, A. G., Fang, Y., van Meurs, J. B. J., van Leeuwen, H. and Pols HAP (2004). Vitamin D receptor gene polymorphisms in relation to Vitamin D related disease states. Journal of Steroid Biochemistry \& Molecular Biology; 89-90:187-193.

26) Morrison, N. A., Yeoman, R., Kelly, P. J. and Eisman, J. A. (1992). Contribution of trans-acting factor alleles to normal physiological variability: vitamin $\mathrm{D}$ receptor gene polymorphism and 
circulating osteocalcin. Proc. Natl. Acad. Sci. USA, 89:6665-6669.

27) Morrison, N. A., Qi, J. C., Tokita, A., Kelly, P. J., Crofts, L., Nguyen, T. V., Sambrook, P. N. and Eisman, J. A. (1994). Prediction of bone density from vitamin D receptor alleles. Nature, 367:284287.

28) Morrison, N. A., Qi, J. C., Tokita, A., Kelly, P. J., Crofts, L., Nguyen, T. V., Sambrook, P. N. and Eisman, J. A. (1997). Prediction of bone density from Vitamin D receptor alleles. Nature. 387:106.

29) Lambrinoudaki, I., Kaparos, G., Armeni, E., Alexandrou, A., Damaskos, C., Logothetis, E., Creatsa, M., Antoniou, A., Kouskouni, E. and Triantafyllou, N. (2011). BsmI vitamin D receptor's polymorphism and bone mineral density in men and premenopausal women on long-term antiepileptic therapy. Eur. J. Neurol., 18(1):93-98.

30) Ma, C., Zhou, Q. L., Deng, Y. J., Liang, X., Wu, D. P. and Dong, Y. Z. (2014). Association of vitamin D receptor BsmI gene polymorphism with risk of low bone mineral density in post-menopausal women: a meta-analysis. Genet. Mol. Res., 13(3):7791-7799.

31) Sigurdsson, G., Magnusdottir, D. N., Kristinsson, J. O., Kristjansson, K. and Olafsson, I. (1997). Association of $B s m I$ vitamin-D receptor gene polymorphism with combined bone mass in spine and proximal femur in Icelandic women. J. Intern. Med., 241(6):501-505.

32) Zajíčková, K., Ofková, I., Bahbouh, R. and Křepelová, A. (2002). Vitamin D Receptor Gene Polymorphisms, Bone Mineral Density and Bone Turnover: FokI Genotype is related to Postmenopausal Bone Mass. Physiol. Res., 51:501509.

33) Uitterlinden, A. G., Fang, Y., Bergink, A. P., Van Meurs, J. B., Van Leeuwen, H. P. and Pols, H. A. (2002). The role of Vitamin $D$ receptor gene polymorphisms in bone biology. Mol. Cell Endocrinol., 197:15-21.

34) Mitra, S., Desai, M. and Ikram Khatkhatay, M. (2006). Vitamin D receptor gene polymorphisms and bone mineral density in postmenopausal Indian women. Maturitas, 55:27-35.

35) Gross, C., Eccleshall, T. R., Malloy, P. J., Villa, M. L., Marcus, R. and Feldman, D. (1996). The presence of a polymorphism at the translation initiation site of the vitamin $\mathrm{D}$ receptor gene is associated with low bone mineral density in postmenopausal Mexican-American women. J. Bone Miner. Res., 11:1850-1855.

36) Falchetti, A., Sferrazza, C., Cepollaro, C., Gozzini, A., Del Monte, F., Masi, L., Napoli, N., Di Fede, G., Cannone, V., Cusumano, G., Pandolfo, M. C., Rini, G. B., Tanini, A. and Brandi, M. L. (2007). FokI polymorphism of the vitamin D receptor gene correlates with parameters of bone mass and turnover in a female population of the Italian island of Lampedusa. Calcif. Tissue Int., 80:15-20.

37) Vidal, C., Grima, C., Brincat, M., Megally, N. and Xuereb-Anastasi, A. (2003). Associations of polymorphisms in the vitamin D receptor gene (BsmI and FokI) with bone mineral density in postmenopausal women in Malta. Osteoporos. Int., 14:923-928.

38) Macdonald, H. M., McGuigan, F. E., Stewart, A., Black, A. J., Fraser, W. D., Ralston, S. and Reid, D. M. (2006). Large-scale population-based study shows no evidence of association between common polymorphism of the VDR gene and BMD in British women. J. Bone Miner. Res., 21:151-162.

39) Langdahl, B. L., Gravholt, C. H., Brixen, K. and Eriksen, E. F. (2000). Polymorphisms the vitamin D receptor gene and bone mass, bone turnover and osteoporotic fractures. Eur. J. Clin. Invest., 30:608617.

40) Morita, A., Iki, M., Dohi, Y., Ikeda, Y., Kagamimori, S., Kagawa, Y., Matsuzaki, T., Yoneshima, H. and Marumo, F. (2004). Prediction of bone mineral density from vitamin $\mathrm{D}$ receptor polymorphisms is uncertain in representative samples of Japanese Women. The Japanese Population-based Osteoporosis (JPOS) Study. Int. J. Epidemiol., 33:979-988.

41) Douroudis, K., Tarassi, K., Ioannidis, G., Giannakopoulos, F., Moutsatsou, P., Thalassinos, N. and Papasteriades, C. (2003). Association of vitamin $\mathrm{D}$ receptor gene polymorphisms with bone mineral density in postmenopausal women of Hellenic origin. Maturitas, 45:191-197.

42) Duman, B. S., Tanakol, R., Erensoy, N., Oztu“rk, M. and Yilmazer, S. (2004). Vitamin D receptor alleles, bone mineral density and turnover in postmenopausal osteoporotic and healthy women. Med. Princ. Pract., 13:260-266.

43) Li, Y., Xi, B., Li, K. and Wang, C. (2012). Association between vitamin D receptor gene polymorphisms and bone mineral density in Chinese women. Mol. Biol. Rep., 39:5709-5717.

44) Ivanova, J., Doukova, P., Boyanov, M. and Popivanov, P. (2006). FokI and BsmI Polymorphisms of the Vitamin D Receptor Gene and Bone Mineral Density in a Random Bulgarian Population Sample. Endocrine, 29:413-418.

45) Feskanich, D., Hunter, D. J., Willett, W. C., Hankinson, S. E., Hollis, B. W., Hough, H. L., Kelsey, K. T. and Colditz, G. A. (1998). Vitamin D receptor genotype and the risk of bone fractures in women. Epidemiology, 9:535-539.

46) Garnero, P., Munoz, F., Borel, O., Sornay-Rendu, E. and Delmas, P. D. (2005). Vitamin D receptor gene polymorphisms are associated with the risk of fractures in postmenopausal women, independently of bone mineral density. J. Clin. Endocrinol. Metab., 90:4829-4835. 
47) Jia, F., Sun, R., Li, Q., Wang, D., Zhao, F., Li, J., Pu, Q., Zhang, Z., Jin, Y., Liu, B. and Xiong, Y. (2012). Vitamin D Receptor BsmI Polymorphism and Osteoporosis Risk: A Meta-Analysis from 26 Studies. Genetic testing and molecular biomarkers, 17: 1-5.

48) Yoldemir, T., Yavuz, D. G., Anik, G., Verimli, N. and Erenus, M. (2011). Vitamin D receptor gene polymorphisms in a group of postmenopausal Turkish women: association with bone mineral density. Climacteric, 14:384-391.

49) Horst-Sikorska, W., Dytfeld, J., Wawrzyniak, A., Marcinkowska, M., Michalak, M., Franek, E., Napio'rkowska, L., Drwe ska, N. and Słomski, R. (2013). Vitamin D receptor gene polymorphisms, bone mineral density and fractures in postmenopausal women with osteoporosis. Mol. Biol. Rep, 40:383-390.

50) Tarner, I. H., Erkal, M. Z., Obermayer-Pietsch, B. M., Hofbauer, L. C., Bergmann, S., Goettsch, C., Madlener, K., Müller-Ladner, U. and Lange, U. (2012). Osteometabolic and osteogenetic pattern of Turkish immigrants in Germany. Exp. Clin. Endocrinol. Diabetes, 120:517-523.

51) Kim, J. G., Kwon, J. H., Kim, S. H., Choi, Y. M., Moon, S. Y. and Lee, J. Y. (2003). Association between vitamin $\mathrm{D}$ receptor gene haplotypes and bone mass in postmenopausal Korean women. American Journal of Obstetrics and Gynecology, 189:1234-1240.
52) Musumeci, M., Vadala, G., Tringali, G., Insirello, E., Roccazzello, A. M., Simpore, J. and Musumeci, S. (2009). Genetic and environmental factors in human osteoporosis from Sub-Saharan to Mediterranean areas. J. Bone Miner. Metab., 27: 424434.

53) Stathopoulou, M. G., Dedoussis, G. V. Z. and Trovas, G. (2011). The role of vitamin D receptor gene polymorphisms in the bone mineral density of Greek postmenopausal women with low calcium intake. Journal of Nutritional Biochemistry; 22:752757.

54) Gennari, L., Becherini, L., Masi, L., Gonnelli, S., Cepollaro, C., Martini, S., Mansani, R. and Brandi, M. L. (1997). Vitamin D receptor genotypes and intestinal calcium absorption in postmenopausal women. Calcif. Tissue Int., 61:460-463.

55) Zambrano-Morales, M., Borjas, L., Fernández, E., Zabala, W., de Romero, P., Pineda, L. and Morales-Machín, A. (2008). Association of the vitamin D receptor gene BBAAtt haplotype with osteoporosis in post-menopausic women. Invest. Clin., 49:29-38.

56) Zhang, Z. L., Zhao, J. X., Meng, X. W., Zhou, X. Y., Xing, X. P. and Xia, W. B. (2003). Association of polymorphisms of vitamin D receptor gene start codon and 3 '-end region with bone mineral density in postmenopausal women. Zhonghua Yi Xue Yi Chuan Xие Za Zhi., 20:5-8. 